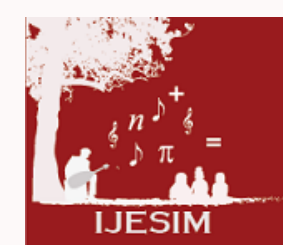

International Journal of Educational Studies in Mathematics

\title{
Major Curriculum Reforms and Controversies in the United States
}

\section{Sinan Kanbir ${ }^{1}$}

\begin{abstract}
This paper identifies and discusses important school mathematics curriculum controversies in the United States of America, over the past 60 years. The first controversy considered here was the "New Math" (1955-1975), and the last is the Common Core State Standard for Mathematics. It summarizes the debates, the main actors, and their viewpoints. The second part of the paper investigates theoretical or research-based evidence related to the controversies. Finally, the last part of this paper investigates short-term and longer-term effects of movements with respect ro intended, implemented, and attained curricula.

Keywords:

Common core, curriculum controversies, curriculum reforms, Euclidean geometry, new math, problem solving, Standards, (c) 2016 IJESIM. All rights reserved
\end{abstract}

Article History:

Received 01.11.2015 Received in revised form 04.12.2015 Accepted 02.01.2016 Available online 30.03.2016

\section{Introduction and Curriculum Theory}

The need to create school mathematics curricula which have a good chance of providing students with the knowledge and skills needed to ensure success in their subsequent college and career lives has always represented a major challenge for mathematics educators. Curriculum theorists have identified three different aspects of curriculum: first, the intended curriculum as represented in local, state- or national-level curriculum standards; second, the implemented curriculum as interpreted and delivered by classroom teachers; and third, the attained curriculum, as learned by students. In this investigation, I will use intendedimplemented-attained distinctions in the Unites States of America to identify and discuss major mathematics curriculum controversies that arose during the period 1955-2015.

\section{The New Math Era (1955-1975): An Intended Curriculum Designed by Mathematicians}

Often, U.S. writers have viewed the "new math" as having been an almost exclusively American set of events, but in fact the new mathematics controversy which raged between 1955 and 1975 was an international phenomenon (Moon, 1986; Singh \& Ellerton, 2013). Following the Soviet Union's launching in 1957 of Sputnik, the U.S. government worked with the Organization for European Economic Cooperation (1961) to organize an international seminar, held in Royaumont, France, for the purpose of developing new thinking in relation to intended and implemented curricula for school mathematics (Moon, 1986). Attendance at the Royaumont seminar was by invitation only, with each participating country being asked to send three delegates: a mathematician, a mathematics educator, and a secondary school teacher (Organization for European Economic Cooperation, 1961). In fact, most of those who attended the Seminar were university-based mathematicians or mathematics educators, with the leadership coming from mathematicians. The Seminar was attended by representatives from 18 countries, 16 of which were

\footnotetext{
${ }^{1}$ Corresponding author's address: Department of Mathematical Sciences, Science Building B246, 2001 Fourth Avenue, Stevens Point, WI 54481

Telephone: +1(715) 346-2120

Fax: +1(715) 346-4260

e-mail: skanbir@uwsp.edu

DOI: http://dx.doi.org/10.17278/ijesim.2016.01.003
} 
European, the other 2 being Canada and the United States. In this article the emphasis will be on the effects of the new math on school mathematics in the United States.

The new math reforms in the U.S. might be seen as having emerged from the convergence of several trends (e.g., national security, the need for a rigorous school mathematics curriculum, doubts about the quality of school mathematics instruction, etc.). The new math era, which in this paper is dated from about 1955 to about 1975, witnessed changes in thinking about the structure of school mathematics, with special attention being given to algebra and geometry. There was a move toward generalized arithmetic, with special emphasis being given to the systematic structure of the set of real numbers, and relationships between that structure and school algebra. Kilpatrick (2014a, 2014b) argued that the major aim of supporters of the new math was to bring school mathematics closer to the college-level mathematics being taught in the university. However, the new curriculum was rushed into the classroom without adequate trials taking place. As Kilpatrick (2014b) has stated: the curriculum reformers "began this process, which a lot of projects have copied, of writing things one summer, trying them out one year, revising them the second summer, and then going out with them" (p. 107).

Many of the leaders of the new math movement believed that the same mathematics should be taught to all students. For example, the textbooks prepared by the SMSG were intended to be used by all students from K through 6 (Kilpatrick, 2012). One issue was whether elementary and secondary school teachers were ready to implement the new curricula. Those opposing the new math believed that changes in the school program needed to be made very carefully, given that the teachers were expected to teach a new curriculum which not only included new topics but also asked for teachers to teach in new ways. There was a huge gap between what teachers had been doing, what they previously understood, and what was being proposed (Kilpatrick, 2014b).

The new math reforms were accompanied by much controversy (Kline, 1973; Moon, 1986; Phillips, 2015). According to Kilpatrick (2012), Morris Kline was the most prominent opponent of the new math. argued against the idea that abstract concepts and principles should be taught before concrete ideas. In 1962, four well-known mathematicians-George Polya, Lipman Bers, Max Schiffer, and Morris Kline-and an additional 61 U.S. and Canadian mathematicians, published a document in the American Mathematical Monthly (Volume 69, pp. 189-193) and The Mathematics Teacher (Volume 55, pp. 192-195) in which they argued that "students should not be introduced to abstractions prematurely" and that "intuitions and conjectures should come before formal proof, and that traditional school mathematics should not be entirely replaced by so-called modern mathematics" (p. 567). It is interesting that although the new math curriculum was, essentially, the brainchild of mathematicians, some mathematicians wanted to blame it on school mathematics teachers. The conflict between mathematicians and educators over the content, goals, and pedagogy of the curriculum would lead to the so-called "math wars" (Bass, 2005).

In addition to the issue of whether teachers would be able to teach the new curricula effectively, there was a debate over the quality of new math textbooks, espcially those prepared by the School Mathematics Study Group (SMSG) and the University of Illinois Committee on School Mathematics (UICSM). The content in those books greatly emphasized both mathematical structures and deductive reasoning, and there was much debate over whether the axiomatic approaches which were adopted were educationally feasible.

\section{Debates on School Geometry}

The content and approaches to geometrical education were also matters of controversy in the new math. There were several questions on many educators' minds: To what extent should school geometry be Euclidean? Non-Euclidean? Both Euclidean and non-Euclidean? Should algebraic notations be used in school geometry? What was the role proof in geometry? How should geometrical proofs be presented? Were two-column proofs still acceptable? If various transformation mappings-such as translations, reflections, rotations, and dilations - were to become commplace in school geometry, what should be their status in proof (Coxford, 1973; Sitimor 1973)?

One of the major themes at the 1959 Royaumont Seminar in France was the role geometry should have in new school curricula. One of the most famous statements at the Seminar came from a French mathematician, Jean Dieudonné, who bluntly called for Euclidean geometry to be eliminated from school mathematics and 
for a much greater emphasis to be given to transformation geometry-with sets of points being mapped by translations, rotations and reflection.

Some researchers (e.g., Eccles; 1972; Finney, 1973; Fehr, 1973) supported large-scale adoption of the transformation approach, but disagreed over whether traditional Euclidean geometrical approaches should still be emphasized (Phillips, 2015). There was controversy over how much time should be devoted to geometry. Howard Fehr (1973), for example, wrote that "the only country to retain a year sequence of a modified study of Euclid's geometry is the United States" (p. 379).

\section{The Back-to-the-Basics and Problem-Solving Eras (1975-1989)}

The perceived failure of the New Math in the United States of America triggered a "back to basics" reactionary movement in the 1970s (Phillips, 2015), and the result was that U.S. school mathematics once again began to emphasize the manipulation of symbols, the solution of equations, and textbook- and teacher-imposed drills. Results by U.S. students on the First International Mathematics Study (FIMS), and the Second International Mathematics Study (SIMS) results were interpreted, by many, as poor, and this provided further stimulus for a return to the pre-New Math emphasis on skills and memorization. The backto-the-basics climate was justified by calls for schools and teachers to adopt "mastery" approaches to learning and instruction inspired by behaviorism (Clements, 2003). Towards the end of 1970s, there was an emphasis on improving the proportion of students who enrolled in the two algebra classes at high schools (Algebra I and Algebra II), and on closing the gender and racial achievement gaps in school mathematics performance.

The National Council of Teachers of Mathematics (NCTM) was not happy with the move to give priority to drilling and memorization and, at the beginning of the 1980s, published its influential An Agenda for Action (NCTM, 1980), in which it argued that "an exclusive focus on basics was wrongheaded" (Schoenfeld, 2004, p. 258). Eventually, the emphasis on back to the basics would give way to NCTM's problem-solving thrust. In the 1980s, there was also increased pressure for the development and implementation of an Algebra for All curriculum. Although equity issues were often put forward to justify calls for "algebra for all," another main reason was the fear that U.S. students were lagging behind students of the same age in their understandings of key mathematical ideas. As Zalman Usiskin (1987) wrote: “The experiences of other countries tell us that algebra can be learned by average students at the eighth-grade level ... Thus, we should expect about 40-50 percent of pupils to learn algebra in eighth grade" (p. 437).

\section{NCTM Standards (1989-2000)}

AT the close of the 1980s NCTM (1989) published its Curriculum and Evaluation Standards for School Mathematics, and in the 1990s it became the template for U.S. school mathematics reform. Then, in 2000, NCTM released a new, and updated, Standards decoument. These Standards documents were historically significant in that for the first time U.S. mathematics educators combined to take an active role in creating new national standards for mathematics which not only incorporated detailed lists of recommended content outputs, but also commentary on desirable teaching and learning methods (Bass, 2005; McLeod, 2003). NCTM's $(1989,2000)$ Standards documents were unique in a number of ways - they were the product of a teachers' organization which took the high ground by preparing and publishing its own curricular expectations and by recommending standards for curriculum development, teaching, and student evaluation. NCTM attempted to go beyond local or state authorities in terms of curriculum and evaluation, and the release of the Standards documents "was accompanied by an unprecedented public relations effort at an especially opportune time" (Kilpatrick, 2014b, p. 331).

Although many mathematicians and scientists feared that standard-based curricula were shallow and weakened classical mathematical values, the NCTM reformers claimed that such curricula reflected a view of mathematics that was deeper and richer than had been the case with traditional curricula (Schoenfeld, 2004). Some of the reformers were committed to discovery learning, and others were driven more by equity and algebra-for-all considerations. During the 1990s there was much criticism that the Standards were not research-based, and the fear that the concerns could be justified became all the more worrisome when, in the second half of the 1990s, results of the International Group for Educational Achievement's (IEA's), international achievement studies became known-U.S. students were found to be performing at levels 
below those of students of the same age in Asian nations such as Singapore, Japan, and Korea (Gonzales et al., 1999; Stigler \& Hiebert, 1999).

Increasing use of externally-set tests and examinations was a major source of controversy during the standards period and, according to Clements (2003), at the grassroots level, "curriculum development was frustrated by teachers who were struggling to keep up with the paperwork demanded by accountability regimes" (p. 1562). Clements observed that numerous reports appeared in the press and many mathematicians criticized the Standards' constructivist orientation. Opponents of the Standards claimed that school mathematics curricula needed to be tougher, and more rigorous (Clements, 2003).

\section{School Mathematics Curricula in the Twentieth Century}

In 2001, not long after the release of NCTM's (2000) Standards, a major controversy arose as a result of the U.S. Government's passing of the No Child Left Behind (NCLB) Act. NCLB required states to articulate curriculum standards for mathematics and, on an annual basis, to assess students' progress (Reys, 2014). Controversy arose on many fronts with respect to the mathematics expectations of NCLB-for example, issues associated with perceived equity and with differences in opportunity were debated, as the readiness of all U.S. students to study algebra was questioned. In 2008, after the release of the report of the National Mathematics Advisory Panel (NMAP), the President of NCTM, Skip Fennel (2008), questioned whether mandating algebra for all eighth-grade students was a good idea because, he argued, some eighth-graders were not ready for formal algebra. He also suggested that more systematic preparation for algebraic thinking should occur in elementary schools.

During the period 2000-2010 the so-called "Math Wars," between some U.S. mathematicians and mathematics educators, intensified to the point where a "Mathematically Correct" group was established with the specific aim of opposing the NCTM Standards (Klein, 2007). The main point of contention seemed to be that those Standards did not define a suuficiently rigorous curriculum, and that, as a result, American students, all over the nation, were not being sufficiently challenged. It was alleged that books which were based on the Standards sometimes presented faulty mathematics, and encouraged teachers to teach in ways that encouraged students to talk together so much that teachers were not able to pass on what students needed to learn. And, as a result, it was alleged, U.S. students performed poorly on international performance tests (Usiskin, 2011).

Common-Core mathematics. In 2009, governors and chief state school officers from 49 U.S. states and territories agreed to develop common standards for English language arts/literacy and mathematics (National Governors Association Center for Best Practices, \& Council of Chief State School Officers. (2010). The mathematics curriculum which was subsequently developed became known as "common-core mathematics." This initiative represented an attempt to end the Math Wars, between the NCTM and those who had opposed NCTM Standards. At the time this paper was being finalized (March 2016), 42 U.S. states were still committed to common-core mathematics and an uneasy truce between mathematicians and mathematics educators seemed to be in place. Representatives from both sides had worked hard to develop a compromise curriculum which featured higher content levels than had been evident in the NCTM Standards and, at the same time, mathematics teaching practices consistent with the old NCTM Standards were emphasized.

Although some commentators (e.g., Wurman \& Wilson, 2012) have argued that the common-core mathematics standards are lower than those of the United States' main international competitors, it should not be assumed that their claims are correct-for example, the common-core standard require that students be introduced to equations and inequalities as early as fifth- grade. Indeed, Kober and Rentner's (2011) widely-accepted survey suggested that the common-core mathematics were pitched at a higher level than the NCTM (2000) standards. 


\section{The Influence of Mathematics Education Research}

\section{Demand for Changes}

The above review suggests that although there was no single force which precipitated changes in U.S. school mathematics during the period 1955-2015, there was always a concern among national leaders that the United States needed to move with clarity and determination to improve the quality of school mathematics intended and implemented curricula.

Calls for greater attention to equity increasingly led to to demands, from policy makers, that steps needed to be taken to increase the proportion of students who enrolled in non-trivial school mathematics courses. But such a demand raised the question of how the desired ends might best be achieved, and such considerations resulted in the mastery learning push of the 1960s and 1970s. Then in the 1980s came NCTM's problemsolving movement, and then, for two decades (1990-2010) NCTM's Standards-based thrusts. All of this was fuelled by a national perception that U.S. students performed poorly in international school mathematics performance studies. This perception resulted in the publication of numerous reports with titles which suggested the need to improve-such as An Agenda for Action (NCTM, 1980), A Nation at Risk (NCEE, 1983), Adding It Up: Helping Children Learn Mathematics (Kilpatrick, Swafford, \& Findell, 2001), the National Mathematics Advisory Panel (U.S. Department of Education, 2008) and, of course, Federal initiatives such as "No Child Left Behind" and "Race to the Top."

Sometimes, curricular changes and mathematics education research were closely related to each other but, more often than not, change was the result of a perception that if a challenging curriculum could somehow be mandated "for all students," and strict accountability introduced and maintained, through statewide and national testing regimes, then improved learning and teachingwould steadily generate improved performances on tests. Mathematics education researchers like to think that in all of this, their work was noticed and had a positive influence, but it is doubtful whether that was in fact the case (Hoyles \& FerriniMundy, 2013). Lesh, Sriraman, and English (2014) claimed that before 1978, there was no program which adequately supported knowledge development in school mathematics, but such a claim is also of doubtful validity (see, e.g., Dienes \& Jeeves, 1965; Skemp, 1977). It is true, though, that before 1970, "there was no professional organization focusing exclusively on mathematics education research or theory development; there was no journal for mathematics education research" (Lesh et al., 2014, p. 622). Links can be found between curriculum theory, school practices, and education research. For example in 2001 after the release of NCTM's (2000) Standards, Jeremy Kilpatrick organized a conference on research foundations at which a number of empirical findings and theoretical conclusions about mathematics teaching and learning were summarized (Siegler, 2003). Researchers offered research-based evidence to support the definition and placement within the curriculum of each topics. In terms of theory, the driving theoretical force behind the Standards movement was constructivism, but may not have been consistent the simultaneously-occurring emphasis on accountability (Clements, 2003).

Not everything in common-core mathematics is consistent with any one particular theory. Bishop's (1977) powerful metaphor of theory as spectacle gives us a strong sense about the use of multiple theories as the "second pair of spectacles." Undergirding common-core mathematics are theories of learning and assumptions about what mathematics school children should learn at different grade levels. One of the dominant theoretical bases, the constructivist approach, views the classroom as an environment where learners are not receiving information or acquiring knowledge by osmosis, but are actively engaged in knowledge building. According to Ernest (2010), "constructivism has been a leading if not the dominant theory or philosophy of learning in the mathematics education research community" (p. 50). Of course, many other theories exist-such as structuralism, outcome-based education, meaningful learning, problem solving, and modeling (Jablonka, Wagner, \& Walshaw, 2013) have been put forward

\section{Short and Longer-Term Effects}

Although the effectsof the new math movement have often been evaluated in negative terms, there can be little dount that the movement generated important curriculum modifications which had long-term effects (Kilpatrick, 2014b). For example, textbooks still refer to sets of numbers and sets of points, and the emphasis on functions remains to this day. Inequalities are still in algebra curricula (Ellerton \& Clements, 2011), and 
loci is studied in geometry classes; trigonometry continues to be introduced by means of real-valued periodic functions (Kilpatrick \& Izsák, 2008). In common-core mathematics, transformation geometry and proof have been resuscitated.

Throughout the period 1955-2015 there has been increasing amounts of controversy within the United States arising from decreasing college-admission test scores. Yet, during the 1980s, students' SAT scores tended to show improvement in comparison with what they had been during the 1960s and 1970s (Educational Testing Service, 1987). According to National Assessment of Educational Progress (NAEP) results, in 1986 and 1988, mathematics proficiency tests scores showed significant improvement among the groups of students aged 9 through 17 (National Assessment of Educational Progress, 1988). But, still U.S. students did not do well on mathematics tests when compared with students of the same age in other many other countries (McKnight, 1987).

Another continuing controversy was whether the introduction of new school mathematics curricula could help to increase the proportion of students continuing with to study higher forms of mathematics. According to the Westat Inc. 1988) report, between 1982 and 1987 there were significant increases in percentages of high school students taking Algebra 1, Algebra 2, and Pre-Calculus courses (Spielhagen, 2011), with, Algebra 1, Algebra 2 and Pre-Calculus enrolments increaseingby 20\%,33\%, and more than $100 \%$, respectively. Courses commonly regarded as lower-level (e.g., General Math, Basic Math) lost favor (Usiskin, 1987), and between 1990 and 1996, following the introduction of NCTM's (1989) Standards, NAEP reported that the percent of twelfth-grade students who had never taken an algebra course dropped from $17 \%$ to $8 \%$. Changing the content of school algebra not only affected what colleges taught prospective teachers in teacher-education courses, but also the kinds of professional development programs that were made available to practicing teachers. These types of shifts produced longer-term effects on school mathematics in the United States.

Today, almost all students graduating from high school have completed Algebra 1, Geometry, and Algebra 2 (Chazan, 2008). This has been one of the effects of the Equity Principle in NCTM's (2000) Principles and Standards for School Mathematics. Since the new math period, the curriculum exemplified by school mathematics textbooks has sgradually been modified, with much greater attention now being given to technology. $\mathrm{Wu}(2014)$ has made the interesting prediction that if teachers gain stronger content knowledge then ultimately they will reject the use of textbooks.

\section{Closing Remarks}

Clements et al. (2013) pointed out that lessons from history of school mathematics over the past 200 years need to be identified and noted. In particular, "we need to make sure that the kind of mathematics put forward as suitable for everyone is indeed suitable for everyone" (p. 33). The demand for algebra for all, for example, will only have a positive influence if it generates forms of mathematics that arise out of the needs of learners and if methods of teaching are devised that are suited to all learners. Previous attempts at significant change have not lasted, and each time educators across the country have reverted back to the traditional curricula and instructional practices (Clements, 2003).

The current debate is still waiting its answers whether the NCLB-inspired, computer-based assessments will provide valid and reliable measures of student learning. But curriculum controversies will be ongoing, not only because there are true believers on all sides but also because "some stand to profit from the conflict" (Clements 2003, p, 281). One might remain convinced that there is a large middle ground, but it is not clear what should be in that middle ground (Niss, 2007).

\section{References}

Bass, H. (2005). Mathematics, mathematicians, and mathematics education. Bulletin of the American Mathematical Society, 42, 417-430. Bishop, A. J. (1977).

Chazan, D. (2008). The shifting landscape of school algebra in the United States. Greenes, C. \& R. Rubenstein (Eds.), Algebra and algebraic thinking in school mathematics: Seventieth yearbook (pp. 19-36). Reston, VA: National Council of Teachers of Mathematics.

Clements, M. A. (2003). An outsider's view of North American school mathematics curriculum trends. In G. M. A. Stanic \& J. Kilpatrick (Eds.). A history of school mathematics (Vol. 2, pp. 1509-1580). Reston, VA: National Council of Teachers of Mathematics.

Clements, M. A., Keitel, C., Bishop, A. J., Kilpatrick, J., \& Leung, F. K. (2013). From the few to the many: Historical perspectives on who should learn mathematics. In M. A. Clements, A. J. Bishop, C. Keitel, J. Kilpatrick \& F. Leung (Eds.), Third international handbook of mathematics education (pp. 7-40). New York, NY: Springer.

Coxford, F. Jr. (1973). A transformation approach to geometry In K. B. Henderson (Ed.), Geometry in the mathematics curriculum (pp. 136201). Washington, DC: National Council of Teachers of Mathematics. 
Dienes, Z. P., \& Jeeves, M. A. (1965). Thinking in structures. London, United Kingdom: Hutchinson Educational.

Eccles, F. M. (1972). Transformations in high school geometry. The Mathematics Teacher, 65(2), 165-169. Retrieved from http://www.jstor.org/stable/27958730

Educational Testing Service. (1987). College bound seniors: 1987 profile of SAT and achievement test takers. Princeton, NJ: Author.

Ellerton, N. F., \& Clements, M. A. (2011). Prospective middle-school mathematics teachers' knowledge of equations and inequalities. In J. Cai \& E. Knuth (Eds.). Early algebraization: A global dialogue from multiple perspectives (pp. 379-408). Berlin, Germany: Springer.

Ernest, P. (2010). Reflections on theories of learning. In B. Sriraman \& L. English (Eds.), Theories of mathematics education: Seeking new frontiers (pp. 39-46). Berlin, Germany: Springer.

Fehr, H. F. (1973). Geometry as a secondary school subject In K. B. Henderson (Ed.), Geometry in the mathematics curriculum (pp. 369-380). Washington, DC: National Council of Teachers of Mathematics.

Fennel, F. (2008). What algebra? When? Reston, VA: National Council of Teachers of Mathematics.

Finney, R. L. (1973). A quick trip through modern geometry, with implication for school curricula. In K. B. Henderson (Ed.), Geometry in the mathematics curriculum (pp. 397-432). Washington, DC: National Council of Teachers of Mathematics.

Gonzales, P., Calsyn, C., Leslie, J., Kitty, M., Kastberg, D., Arafeh, S., Williams, T., \& Tsen, W. (2000). Pursuing excellence: Comparisons of international eighth-grade mathematics and science Achievement from a U.S. perspective, 1995 and 1999: Initial findings from the Third International Mathematics and Science Study - Repeat. Washington, D.C.: U.S. Department of Education.

Hoyles, C., \& Ferrini-Mundy, J. (2013). Policy implications of developing mathematics education research. M. A. Clements, A. J. Bishop, C. Keitel, J. Kilpatrick \& F. Leung (Eds.), Third international handbook of mathematics education (pp. 485-515). New York, NY: Springer

Jablonka, E., Wagner, D., \& Walshaw, M. (2013). Theories for studying social, politiucal and cultural dimensions of mathematiocs education. In M. A. Clements, A. J. Bishop, C. Keitel, J. Kilpatrick \& F. Leung (Eds.), Third international handbook of mathematics education (pp. 41-68). New York, NY: Springer.

Kilpatrick, J. (2012). The new math as an international phenomenon. Zentralblatt für Didaktik der mathematik, 44, 563-571.

Kilpatrick, J. (2014a). Mathematics education in the United States and Canada. In A. Karp \& G. Schubring (Eds.), Handbook on the history of mathematics education (pp. 323-333). New York, NY: Springer.

Kilpatrick, J. (2014b). Interview with Jeremy Kilpatrick. In A. Karp \& D. L. Roberts(Eds.). Leaders in Mathematics Education: Experience and Vision. Springer.

Kilpatrick, J., \& Izsák, A. (2008). A history of algebra in the school curriculum. In C. Greenes \& R. Rubenstein (Eds.). Algebra and algebraic thinking in school mathematics: 70th Yearbook (pp. 3-18). Reston: VA: National Council of Teachers of Mathematics.

Klein, D. (2007). A quarter century of US "math wars" and political partisanship. BSHM Bulletin, 22(1), 22-33.

Kline, M. (1973). Why Johnny can't add: The failure of the New Math. New York: St Martin's Press.

Kober, N., \& Rentner, D.S. (2011, Sepember 14). Common Core State Standards: Progress and Challenges in School Districts' Implementation. Washington, DC: Center on Education Policy. Retrieved October 2, 2012, from http://www.corestandards.org/in-the-states/

Lesh, R., Sriraman, B., \& English, L. (2014). Theories of learning mathematics. In S. Lerman (Ed.), Encyclopedia of mathematics education (pp. 615-622). Dordrecht, The Netherlands: Springer.

Moon, B. (1986). The "new maths" curriculum controversy: An international story. London, United Kingdom: The Falmer Press.

McKnight, C. C. (1987). The underachieving curriculum: Assessing U.S. school mathematics from an international perspective. A national report on the Second International Mathematics Study. Champaign, IL: Stipes Publishing.

McLeod, D. B. (2003). From consensus to controversy: The story of NCTM Standards. In G. M. A. Stanic \& J. Kilpatrick (Eds.). A history of school mathematics (pp. 753-818). Reston, VA: National Council of Teachers of Mathematics.

National Assessment of Educational Progress. (1988). The report card: Progress toward excellence in our schools (Report No. 15-R-01). Princeton, NJ: Educational Testing Service, National Assessment of Educational Progress.

National Council of Teachers of Mathematics. (1989). Curriculum and evaluation standards for School mathematics. Reston, VA: Author.

National Council of Teachers of Mathematics. (2000). Principles and standards for school mathematics. Reston, VA: Author.

National Governors Association Center for Best Practices, \& Council of Chief State School Officers. (2010). Common Core State Standards for Mathematics. Washington, DC: National Governors Association Center for Best Practices and the Council of Chief State School Officers.

Niss, M. (2007). Reflections on the state of and trends in research on mathematics teaching and learning: From here to Utopia. In F. Lester (Ed.), Second handbook of research on mathematics teaching and learning (pp. 1293-1312). Charlotte, NC: Information Age Publishing.

Organization for European Economic Cooperation. (1961). New thinking in school mathematics. Paris: Author.

Phillips, C. J. (2015). The new math: A political history. Chicago, IL: University of Chicago Press.

Reys, B. J. (2014). Mathematics curriculum policies and practices in the U.S.: The Common Core State Standards initiative. In Y. Li \& G. Lappan (Eds.), Mathematics curriculum in school education (pp. 35-48). Dordrecht, The Netherlands: Springer.

Schoenfeld, A. H. (2004). The math wars. Educational Policy, 18, 253-286.

Siegler, R. S. (2003). Implications of cognitive science research for mathematics education. In J. Kilpatrick, W. B. Martin, \& D. E. Schifter (Eds.), A research companion to principles and standards for school mathematics (pp. 219-233). Reston, VA: National Council of Teachers of Mathematics.

Sitomer, H. (1973). Geometry in an integrated program. In K. B. Henderson (Ed.), Geometry in the Mathematics Curriculum (pp. 303-333). Washington, DC: National Council of Teachers of Mathematics

Singh, P., \& Ellerton, N. F. (2013). International collaborative studies in mathematics education. In M. A. Clements, A. J. Bishop, C. Keitel, J. Kilpatrick \& F. Leung (Eds.), Third international handbook of mathematics education (pp. 827-860). New York, NY: Springer.

Skemp, R. R. (1977) Relational understanding and instrumental understanding, Mathematics Teaching, 77, 20 -26.

Spielhagen, F. R. (2011). The algebra solution to mathematics reform: Completing the equation. New York, NY: Teachers College Press. 
Stigler, J. S., \& J. Hiebert (1999). The teaching gap: Best ideas from the world's teachers for improving education in the classroom. New York: Free Press.

U.S. Department of Education. (2008). The final report of the National Mathematics Advisory Council. Jessup, MD: Author.

Usiskin, Z. (1987). Why elementary algebra can, should, and must be an eighth-grade course for average students. The Mathematics Teacher, 80, 428-438.

Usiskin, Z. (2011, April 15).The common core: Where do we go from here? Indianapolis, IN. Retrieved from http://www.nctm.org/uploadedfiles/conferences/webcasts/zusiskin nctm 2011 ccs final.pdf

Westat, Inc. (1988). Preliminary tabulations: Nation at risk update study as part of the 1987 high school transcript study (Report prepared for the U.S. Dept. of Education, Center for Education Statistics). Rockville, MD: Author.

Wu, H. H. (2014). Potential impact of the common core mathematics standards on the American curriculum. In Y. Li \& G. Lappan (Eds.), Mathematics curriculum in school education (pp. 119-142): New York, NY: Springer.

Wurman, Z., \& Wilson, S. W. (2012). The common core math standards are they a step forward or backward? Education Next, 12, 44-45 